Published in final edited form as:

Nat Geosci. 2020 January ; 13(1): 8-16. doi:10.1038/s41561-019-0513-5.

\title{
Manifestations and mechanisms of the Karakoram glacier Anomaly
}

\author{
Daniel Farinotti ${ }^{1,2,0000-0003-3417-4570}$, Walter W. Immerzeel ${ }^{3,0000-0002-2010-9543}$, Remco de \\ Kok $^{3,0000-0001-6906-2662, ~ D u n c a n ~ J . ~ Q u i n c e y 4,0000-0002-7602-7926, ~ A m a u r y ~}$ \\ Dehecq $^{1,2,0000-0002-5157-1183}$
}

${ }^{1}$ Laboratory of Hydraulics, Hydrology and Glaciology (VAW), ETH Zurich, Zurich, Switzerland ${ }^{2}$ Swiss Federal Institute for Forest, Snow and Landscape Research (WSL), Birmensdorf, Switzerland ${ }^{3}$ Department of Physical Geography, Faculty of Geosciences, Utrecht University, Utrecht, The Netherlands ${ }^{4}$ School of Geography, University of Leeds, Leeds, United Kingdom

\section{Abstract}

Global-scale glacier shrinkage is one of the most prominent signs of ongoing climatic change. However, important differences in glacier response exist at the regional scale, and evidence has accumulated that one particular region stands out: the Karakoram. In the past two decades, the region has shown balanced to slightly positive glacier budgets, an increase in glacier ice-flow speeds, stable to partially advancing glacier termini, and widespread glacier surge activity. This is in stark contrast to the rest of High Mountain Asia, where glacier retreat and slowdown dominate, and glacier surging is largely absent. Termed the Karakoram Anomaly, recent observations show that the anomalous glacier behaviour partially extends to the nearby Western Kun Lun and Pamir. Several complementary explanations have now been presented for explaining the Anomaly's deeper causes, but the understanding is far from being complete. Whether the Anomaly will continue to exist in the coming decades remains unclear, but its long-term persistence seems unlikely in light of the considerable warming anticipated by current projections of future climate.

Daniel Farinotti: 0000-0003-3417-4570

Walter W. Immerzeel: 0000-0002-2010-9543

Remco de Kok: 0000-0001-6906-2662

Duncan J. Quincey: 0000-0002-7602-7926

Amaury Dehecq: 0000-0002-5157-1183

Users may view, print, copy, and download text and data-mine the content in such documents, for the purposes of academic research, subject always to the full Conditions of use:http://www.nature.com/authors/editorial_policies/license.html\#terms

Correspondence and requests for materials should be addressed to D.F.

Data availability: The data shown in the individual Figures are available through the original publications (cited).

Code availability: The code used to produce Figures 2 and 3 is available upon request.

Author contributions DF initiated the article, designed the figures and led the writing, to which all authors contributed. WWI and DQ provided materials for Figure 1 and Box 1. AD provided materials for Figures 1 and 2 . The analyses shown in Figure 3 and Supplementary Figures S2 and S3 were performed by RdK. RdK and WWI conceived Figure 4, with additions from AD, DF, and DQ.

Reprints and permissions information is available online at www.nature.com/reprints.

Competing financial interests The authors declare no competing financial interests. 
The Karakoram is the mountain range spanning the borders of Pakistan, India, and China, with extremities reaching into Afghanistan and Tajikistan (Figure 1a). The region is geomorphologically very dynamic ${ }^{1}$, with intense interactions between tectonic, fluvial, and mass movement processes. The extremely steep and high topography, characteristic of the region, hosts some of the tallest mountains on Earth, and very dynamic glaciers (Box 1). According to current inventories ${ }^{2}$, the region features roughly 13,700 glaciers, covering an area of about $22,800 \mathrm{~km}^{2}$. The total glacier ice volume is estimated to be in the order of $2,200 \mathrm{~km}^{3}$, or about $30 \%$ of the total for High Mountain Asia ${ }^{3}$.

Together with snowmelt, runoff from glaciers is the primary water source for the region's rivers ${ }^{4}$, which include tributaries of both the Tarim and the Indus (Figure 1a). This makes the Karakoram's glaciers of utmost importance in supplying water to millions of people downstream ${ }^{5-7}$. Glacier melt has been shown ${ }^{8}$ to be of particular importance during periods of drought stress, and hence to contribute to social stability in an otherwise conflict-prone region. Against this background, characterizing the region's glacier evolution is of great relevance.

A peculiar behaviour of Karakoram glaciers was already suspected in early reports ${ }^{9-12}$ of $19^{\text {th }}$ century explorers. It is difficult to ascertain, however, whether or not the reports were not biased by the perception of an unusually dramatic landscape. Modern observations, instead, are more conclusive, and indeed indicate that - at least for the past decades Karakoram's glaciers experienced a different evolution when compared to other regions on Earth. The most important difference is the regional glacier mass budget. At the worldwide scale, glaciers outside the Greenland and Antarctic ice sheets have lost an estimated13 $9,625 \pm 7,975 \mathrm{Gt}\left(1 \mathrm{Gt}=10^{12} \mathrm{~kg}\right)$ between 1961 and 2016 , or $480 \pm 200 \mathrm{~kg} \mathrm{~m}^{-2}$ per year. This is in direct contrast to what is reported for the central parts of the Karakoram, where most recent estimates ${ }^{14}$ indicate a mass gain in the order of $120 \pm 140 \mathrm{~kg} \mathrm{~m}^{-2}$ per year. This slight glacier mass gain has likely contributed to an increase in ice flow velocities observable at the regional scale ${ }^{15}$.

The frequent occurrence of glacier surges ${ }^{16}$ is a second distinguishing characteristic of the Karakoram. Glacier surges are irregular phases of ten- to hundredfold acceleration in glacier flow, typically lasting between a few months to years ${ }^{17}$. Although surges occur in other regions on Earth as well (including Alaska and Svalbard, for example), they are absent for most other parts of High Mountain Asia ${ }^{18}$. In an overview from the $1930 \mathrm{~s}^{19}$, such behaviour was attributed to "accidental changes", and was thought to be responsible for the high number of river-floods caused by the outburst of glacier-dammed lakes. Today, various mechanisms have been proposed to explain glacier surges initiation and clustering (Box 2) but the understanding is far from being complete. Similarly, it remains unclear whether the frequency of Karakoram glacier surges has changed over time, although indications exist ${ }^{20}$ that surge-activity might have increased after 1990.

The above peculiarities in glacier behaviour are often referred to as the Karakoram Anomaly, a term coined in the mid-2000s (ref. ${ }^{21}$ ) when indications for anomalous glacier behaviour started to emerge (see Supplementary Section S1 for a brief history on how the idea of a Karakoram Anomaly developed). In the following, we detail the ways in which this 
Anomaly expresses itself, and review the mechanisms that have been proposed to explain it. We distinguish between early, partially speculative explanations, and more recent, holistic interpretations. We highlight the remaining gaps in the explanation chains, speculate about the Anomaly's implications and future evolution, and suggest avenues for future research.

\section{Manifestations of the Karakoram Anomaly}

Slight glacier mass gains and widespread surging activity are the two most prominent features of the Karakoram region. Evidence for the former has accumulated since satellitebased, regional-estimates of glacier surface elevation changes have become available ${ }^{22-26}$. Although patterns of glacier changes are spatially variable (Figure 2), there is now general agreement that the Karakoram experienced balanced glacier budgets, or even marginal glacier mass gains in the early $21^{\text {th }}$ century ${ }^{13,14,27}$. The most recent studies ${ }^{14,26,28}$, however, indicate that the signal of positive glacier budgets is not centred over the Karakoram itself, but rather over its eastern part and the Western Kun Lun (circles in Figure 2; uncertainties shown in Supplementary Fig. S1). The western part of the Karakoram, showing balanced mass budgets, is thus to be understood as a region of transition between negative mass balances in the Pamir and slightly positive mass balances in Western Kun Lun. Interestingly, regional-scale surface-elevation changes neither show significant differences between debris-covered and clean-ice glaciers ${ }^{22,} 29$ nor between surge-type glaciers and glaciers that do not surge 24 .

The slightly positive mass budgets in parts of the Karakoram and Western Kun Lun are also indirectly confirmed by long-term trends in glacier ice-flow velocities (arrows in Figure 2; uncertainties shown in Supplementary Figure S1). Even if glacier-specific velocity changes can be difficult to interpret because of large seasonal and interannual variability 16,30 , analyses over the period 2000-2016 show ${ }^{15}, 31$ velocity changes in the order of 0 to $+20 \%$ per decade. Regional-wide averages for the Karakoram and the Western Kun Lun are of $+3.6 \pm 1.2 \%$ and $+4.0 \pm 2.1 \%$ per decade, respectively ${ }^{15}$. This trend in ice flow velocities was shown to be unrelated to the region's surging glaciers ${ }^{15}$, and thus interpreted as an indication of increased ice deformation and sliding due to glacier thickening. The thickening is in turn consistent with the positive glacier mass budgets. The findings of accelerating glacier flow are in contrast to what has been observed in other parts of High Mountain Asia, where iceflow slowdown dominates ${ }^{15,32}$.

The dynamic adjustments to positive mass budgets are also manifested in the majority of the region's glaciers showing stable or advancing termini ${ }^{33,34}$. Albeit not resulting in significant net change in glacier area ${ }^{35}$, these changes are again in contrast to the rest of High Mountain Asia, where glacier-terminus retreat and area loss largely prevails ${ }^{36,37}$. It must be noted, however, that the detection and interpretation of changes in the region's glacier extents are complicated by the widespread debris-coverage ${ }^{33}$. The debris-covered area itself remained virtually unchanged in the central part of the Karakoram over the last four decades ${ }^{38}$, and increased by about $11 \%$ over a larger extent and the shorter 2001-2010 period?. This further corroborates the balanced (slightly negative) mass budgets reported for the central (eastern) part of the Karakoram ${ }^{14}$, given that positive and negative mass budgets would be expected to result in a reduction and an extension of the debris-covered area, respectively. 
Many terminus advances and changes in velocity may also be ascribed to glacier surges. The phenomenon is uncommon elsewhere in High Mountain Asia but is widespread in the Karakoram ${ }^{16}$ and the nearby regions ${ }^{31,39,40}$. It has been suggested that this clustering of surge-type glaciers might be related to particular climatic and geometric conditions that lead to periodic enthalpy imbalances ${ }^{18}$, but the specific controls on surging remain unclear. This is also because data on englacial and subglacial conditions, understood to be pivotal in controlling surge cycles (Box 2), are lacking almost entirely ${ }^{16}$. The frequency of surge events seems to have increased in recent decades ${ }^{20}$, potentially correlating with a period of warming atmospheric temperatures ${ }^{40}$ and increasing precipitations ${ }^{20}$. No definitive connection between surge activity and changes in external forcing has however been established yet ${ }^{41}$, and it is still difficult to discern whether the reported increase in surge frequency is related to a real environmental trend, or to an improved ability to detect surges through advances in observational techniques.

A further open question is for how long the observed anomalous behaviour might have persisted. Early works based on sparse field observations suggest a retreat of the Karakoram glaciers between 1940 and the 1960s (ref. ${ }^{42}$ ), with periods of slight advances in the late 1970s and 1990s (ref. ${ }^{43}$ ). Meta-analysis of reports for glacier changes across High Mountain Asia, however, indicates that no significant change occurred since the $1960 \mathrm{~s}^{37}$. The only field-based mass balance estimate available for the 20th century in the region ${ }^{44}$ (Siachen glacier) is negative but very uncertain ${ }^{45}$. Satellite-based estimates, on the other hand, reach back to 1973, and suggest that nearly-balanced glacier budgets might have persisted since then for the Karakoram ${ }^{46,47}$, the western Kun $\operatorname{Lun}^{48,49}$, and the eastern Pamir ${ }^{50,51}$. Also in this case, however, uncertainties are large, and the temporal resolution of such estimates is low - typically only providing information for the period 1973-2000, or for 1973 and later. All of this makes it difficult to establish temporal variations in the Anomaly's magnitude and extent.

\section{Early explanations of anomalous behaviour}

Early explanations ${ }^{52,53}$ for a potentially-anomalous behaviour of Karakoram glaciers often invoked the substantial debris cover that characterize the glaciers of the region, although it was known that debris covered glaciers were widespread in other parts of High Mountain Asia as well. The debris cover was not only suggested to significantly suppress ice melt in the ablation zones, thus preventing glacier wastage and retreat, but was also suspected ${ }^{21}$ to make it difficult to detect glacier changes. The morphology of the glaciers in the Karakoram remained one of the main explanations when the idea of a Karakoram Anomaly was proposed in the mid-2000s: the confinement of the main glacier trunks by characteristically high and steep headwalls (Box 1) was suggested to cause an "elevation effec" 43 , i.e. an orographic enhancement of high-altitude precipitation and a related downslope concentration of snowfall driven by avalanches. Combined with an all-year-round accumulation regime, the effect would cause limited sensitivity to warming, since a rise in temperature would only result in a small decrease of the accumulation area.

Indications of a climatic control for the Karakoram's peculiar glacier behaviour emerged in the early 2000s. Archer and Fowler ${ }^{54,55}$ analysed 1961-2000 trends in temperature and 
precipitation for meteorological stations in the region, and identified a significant increases in winter, summer and annual precipitation ${ }^{54}$ as well as a lowering of summer mean and minimum temperatures ${ }^{55}$. These observations were independently supported ${ }^{56,57}$ by data obtained from tree rings, which indicated that the western Himalaya saw pre-monsoon (March-May) cooling in the latter part of the $20^{\text {th }}$ century ${ }^{56}$. For the Karakoram, the $20^{\text {th }}$ century was even shown ${ }^{57}$ to have been the wettest over the past millennium. Combined, the decrease in summer temperatures and increase in precipitation was suggested to be consistent with positive glacier mass balances in the region, an interpretation further supported by the simultaneous decrease in summer river flows ${ }^{54}$. This line of argument was echoed and amplified by a number of subsequent studies ${ }^{20,22,33,58,59}$, making it the generally-accepted hypothesis for the Karakoram Anomaly by about 2010.

The deeper causes of the observed temperature and precipitation changes, however, remained elusive. A preliminary analysis ${ }^{54}$ identified a significant positive (negative) correlation between winter (summer) precipitation and the North Atlantic Oscillation, whilst later investigations ${ }^{60}$ showed that the westerly jet stream over central Asia - a central mechanism for regional moisture transport during winter (Box 3) - had strengthened and shifted to both lower elevations and lower latitudes between 1979 and 2001. These observations remain central to present-day understanding of potential drivers of change (see Current understanding of the Anomaly's drivers).

Concerning the widespread occurrence of glacier surges, it was recognized very early that substantial basal sliding must be involved to maintain high rates of glacier flow. Based on a set of observations collected during the 1930s, for example, Finsterwalder ${ }^{61}$ suggested that the glaciers of the Nanga Parbat area mainly move through "blockschollen-motion", i.e. sliding-dominated plug-flow, primarily resisted by drag at the glacier margins. The important contribution of basal sliding to the total motion of both surge-type and nonsurging glaciers in the Karakoram was confirmed repeatedly through both groundbased ${ }^{62-66}$ and remote-sensing observations ${ }^{67}$. Whether and why such high sliding rates are peculiar to the region, however, remains largely unknown.

To explain surge initiation, the literature generally focuses on two main mechanisms, that invoke changes in either thermal or hydrological conditions as the trigger (Box 2). Which of the two is predominant for the Karakoram has been debated ${ }^{68}$. Quincey et al..$^{59}$ argued in favour of thermal control, noticing that surges develop over several years and that no seasonality can be discerned in their initiation. In contrast, Copland et al. ${ }^{20}$ favoured hydrological control since the active phase of Karakoram surges seems to be short-lived and separated by decades-long phases of quiescence. To explain the increase in surging activity after the 2000s, Hewitt ${ }^{68}$ speculated about the role of changes in climate, stating that "response to climate change seems the only explanation for [the] events at [four tributaries of] Panmah Glacier [Central Karakoram]'. Demonstrating such a climatic control, however, is difficult, and evidence remains scant. 


\section{Current understanding of the Anomaly's drivers}

Whilst a climatic control on surging activity is debated, the positive glacier budgets in and around the Karakoram must be associated to the meteorological forcing. Compared to other parts of High Mountain Asia, the latter must either favour more accumulation, less ablation, or a combination of both. Currently, a number of potential explanations are found in the literature, and include increased snowfall in the accumulation zones, or a suite of factors including increased cloud cover and a higher surface albedo - that reduce the net energy available for the melting of snow and ice.

The Karakoram's general meteorological characteristics are well established ${ }^{69-71}$ (Box 3). In winter, when the westerly jet is located south of the Karakoram, mid-latitude cyclones (or westerlies) control the region's weather ${ }^{72,73}$. Their associated fronts interact with the extreme topography and can provide heavy mountain precipitation ${ }^{74}$. An increase in strength and frequency of such westerly-dominated precipitation has been identified ${ }^{75}$ for the period 1979-2010, and seems to have led to a slight increase in the region's winter snowfall ${ }^{76}$. This is in contrast to other regions in High Mountain Asia, where snowfall trends are mostly negative ${ }^{69}$. The contrasting trends in the geopotential height between different parts of High Mountain Asia (Figure 2 in ref. ${ }^{76}$ ) have been suggested to be at the origin of the changes in westerlies-driven precipitation events ${ }^{70,75,76}$, but the underlying mechanisms are still unclear. The precipitation changes, in turn, have been proposed to exert a strong control on regional glacier mass balances $69,70,77$. It has to be noted, however, that precipitation trends are uncertain and mostly non-significant ${ }^{78}$, and that no increase in Karakorams total precipitation is evident in recent meteorological reanalyses (Figure $3 \mathrm{~b}$ and Supplementary Figure $\mathbf{S} 2 b+d)$.

In summer, the interplay between the monsoon and mid-latitude westerlies is complex, and results in a high inter-annual precipitation variability ${ }^{69}$. This variability has been associated $^{70,71}$ to modulations of the Karakoram / Western Tibetan Vortex, an atmospheric structure extending from the near surface to almost the tropopause ${ }^{70}$ ). Temperatures show variability as well, and for the latter part of the $20^{\text {th }}$ century, an increase in diurnal temprature ranges has been inferred from both weather stations 55,79 and tree-rings ${ }^{56}$. This increase has been related to large-scale deforestation, which caused a lowering of the soil's thermal inertia due to reduced water infiltration ${ }^{56}$. A cooling of summer temperatures was observed concomitantly. The cooling was particularly pronounced in the 1960-1980 period $^{55,79}$, occurred despite a general warming trend ${ }^{79}$, and has been attributed to a weakening of the monsoon ${ }^{70,71}$. It is this summer cooling that has been suggested ${ }^{55,70}$ to be a particularly important driver for the balanced glacier budget of the Karakoram in recent decades. It shall be noted, however, that work from tree-ring chronology at one highelevation site ${ }^{80}$ did not provide any indication for Karakoram temperatures being out of phase with other regions in High Mountain Asia over centennial timescales.

Changes in glacier accumulation and ablation have also been suggested ${ }^{81}$ to be linked to increased evaporation in Northwest China during the $20^{\text {th }}$ centruy. This increased evaporation - caused by a dramatic increase in irrigation after 1960 (ref. ${ }^{82}$ ) - has caused a rise in atmospheric moisture, which in turn seems to have resulted in more frequent summer 
snowfalls in the Western Kun Lun and the Pamir. The increased atmospheric moisture also increased cloudiness and reduced incoming shortwave radiation ${ }^{81}$ (Figure $3 \mathrm{c}$ ), thus reducing ice and snow ablation. This hypothesis is finding support in both observational records and modelling ${ }^{76,83}$, but cannot be considered as conclusive yet.

Although often assessed independently, the monsoon-weakening and irrigation hypotheses are in fact inherently interconnected. The weakening of the monsoon has been suggested to be a partial consequence of changes in irrigation itself ${ }^{84,85}$ : Increased irrigation causes changes in near-surface heat fluxes, which lead to a cooling of both the surface and the lower troposphere; the troposphere cooling, in turn, decreases the geopotential height over the irrigated regions, thus affecting atmospheric circulation including the westerly jet and the monsoon ${ }^{84}$. Such changes in large-scale circulation would partly explain regional differences in glacier response, and the different glacier budgets in the Karakoram with respect to other regions in High Mountain Asia.

Regional differences in glacier response are also affected by spatial variations in climate sensitivity ${ }^{86}$. The response of glacier mass balance to a given change in temperature, for example, was shown to vary ${ }^{87}$, and to correlate well with observed mass budgets itself. These differences can be explained by regional variations in the glaciers' energy balance. Both field- $-88,89$ and model-based ${ }^{90}$ investigations, in fact, indicate that net shortwave radiation is more important in driving glacier melt in the Karakoram than it is in other parts of High Mountain Asia. Since the shortwave radiation budget is decisively controlled by surface albedo and cloudiness, this partly explains why glaciers in the Karakoram might be particularly susceptible to changes in albedo-enhancing summer snowfalls. The increase in summer snowfall and the decrease in net shortwave radiation observed in the Karakoram over the last decades (Figure 3c) might thus have favoured positive glacier budgets, whilst the increases in both temperature and net longwave radiation in other parts of High Mountain Asia (Figure 3a+d) favoured glacier mass loss.

\section{Knowledge gaps, implications, and a look into the future}

The Karakoram's balanced to slightly-positive glacier mass budgets are the strongest argument for an anomalous behaviour, both at the scale of High Mountain Asia and globally. Moreover, enough evidence now exists to show that these close-to-balance glacier budgets partially extend to the neighbouring Western Kun Lun and Pamir. When calling for an Anomaly, however, qualitatively different glacier behaviour must be distinguished from regional characteristics. Large, low-elevation and debris-covered glacier termini; strong verticality resulting in pronounced avalanches nourishment; and even the high number of surge-type glaciers might, in fact, rather be considered as a characteristic of the region than an anomaly ${ }^{91}$.

Figure 4 provides an overview of the process-chain related to the Anomaly, with a focus on the evolution observed during the past decades. In a nutshell, the interplay between land cover, atmospheric processes, and climate change (Figure 4, point 1) is suggested to have led to summer cooling, increased snowfalls, and reduced net energy available for glacier melt (Figure 4.2). In conjunction with specific glacier properties (Figure 4.3), a combination of 
these effects resulted in glacier advance, constant to slightly-accelerating glacier ice flow, and insignificant changes in both total glacier area and debris cover (Figure 4.4). This, in turn, reduced downstream flows, and affected glacier-related hazards in some occasions (Figure 4.5). The mechanisms that control the region's glacier peculiar behaviour, including glacier surging for example, are however far from being completely understood. Based on our expert judgement and the reviewed literature, we assigned a relative level of confidence to the degree to which individual elements of Figure 4 are characterized or understood.

The lack of long-term observations, for instance, causes uncertainties in the trend-estimates for factors that drive glacier change. In the Karakoram and nearby regions, this is particularly true for meteorological parameters (Figure 4.2). Air-temperature trends obtained from high-resolution climate models ${ }^{76}$, for example, show large differences when compared to climate reanalysis products ${ }^{92}$ (Supplementary Figure S2a,c). Precipitation trends show better agreement, although the trends themselves are less certain (Supplementary Figure S2b,d). High-altitude precipitation is particularly poorly quantified, both in terms of temporal and spatial variability, as well as in elevation dependency. Together with the difficulty in characterizing snow transport by wind and avalanches, this makes the estimates of glacier accumulation highly uncertain. The identification of trends is also complicated by the region's high inter-annual climate variability. The latter results in low statistical significance (Supplementary Figure S3) and slow trend emergence, which both complicate attributive studies. The use of climate model ensembles, rather than individual products, can increase the robustness of such studies, but cannot overcome the lack of ground-truth information. This lack decisively affects the level of confidence with which drivers of the Karakoram's glacier budgets can be identified.

The present-day understanding of the mechanisms that control the region's glacier behaviour is often based on model simulations which use simplified parameterisations for representing important glaciological (Figure 4.3) or atmospheric (Figure 4.1) processes ${ }^{93}$. Both introduce uncertainties that are difficult to quantify. The continuous development towards models with higher spatial resolution and complexity is unlikely to resolve this. Whilst some driving processes might be indeed better represented in higher-resolution models, a strong need remains for direct observations that support model calibration and validation. Crucially, such observations need to cover time spans pertinent to glacier changes, and need to be representative in both resolution and spatial coverage. Such observations also hold the key for increasing the understanding of individual processes and process-chains, which in turn is the prerequisite for improving model parametrisations. Bridging the gap between in-situ observations and model simulations remains one of the major challenges when aiming at gaining further insights in the Anomaly's deeper causes.

While surface parameters such as glacier extents, topography, and their temporal evolution (top of Figures 4.3 and 4.4) are observed with increasing accuracy due to advances in remotesensing techniques, detailed information on subsurface characteristics such as the glaciers' thermal regimes, hydrological systems, and subglacial lithology (Figures 4.3 and 4.4 , bottom) remain out of reach. This hampers a robust analysis of the physical processes that control local glacier behaviour. For the Karakoram, this is particularly relevant in the context of the region's surging activity. Advances in the conceptual understanding of surge 
occurrences are being made ${ }^{18,94}$ but a convincing explanation for why surge-type glaciers are clustered in the Karakoram is still missing, and surge behaviour is far from being predictable. Indications that the spatial distribution of surge-type glaciers is importantly controlled by climate now exist ${ }^{18}$ but a better characterisation of englacial and subglacial properties would certainly add to the understanding. Better constraining the controls on regional surge activities seem particularly important in light of recent indications that environmental changes may influence catastrophic, surge-like glacier collapses ${ }^{95,} 96$ (Figure 4.5).

A presently unanswered question is for how long the Anomaly is likely to persist in the future. If the global climate continues to warm as anticipated by current projections ${ }^{97}$, it seems unlikely that it will persist in the longer term - especially not in the form of positive glacier budgets ${ }^{7,98}$. Changes in precipitation will affect the future evolution as well. Here, a key uncertainty is how the monsoon system and westerly jet will respond to ongoing warming, and to other forcings including land-use changes. At present, irrigation is suggested to influence the region's climate through the control of heat exchanges and moisture fluxes ${ }^{84,85}$. Irrigated areas, however, cannot continue to expand limitlessly since space is scarce and water resources are limited, and might even shrink if groundwater levels drop beyond economically viable depths. If recent hypotheses on regional-scale mechanisms ${ }^{81}$ are accepted, such land-use changes could result in decreased precipitation, possibly affecting the region's glaciers via reduced accumulation.

The anomalous glacier behaviour in the Karakoram and its neighbouring regions is not only a curiosity in an epoch dominated by glacier retreat. The glaciers' importance for regional water supplies ${ }^{7,8}$ (Figure 4.5), and the cultural and religious value attributed to glaciers by the local communities and their traditional practices ${ }^{99}$ make some of the unanswered scientific questions of great societal relevance. Future glacier evolution, and the effect on both water supplies and glacier related hazards, are of particular concern in this geopolitically complex region where communities have limited resilience to environmental stress. Establishing the mechanisms that are driving the Karakoram Anomaly, their relative importance, and how they are likely to evolve in coming decades, therefore remains a key challenge for climatic and cryospheric researchers alike.

\section{Methods}

The trend analyses displayed in Figure 3 are based on the ERA5 climate reanalysis dataset $^{92}$. ERA5 provides global-scale meteorological information at a horizontal resolution of $\approx 31 \mathrm{~km}$ and covering the period 1979 to present. The information stems from an ensemble of ten model members, for which we only consider the ensemble mean (ERA5 standard product). Trends were calculated independently for each grid cell through linear fitting of the accumulated annual or summer values.

\section{Supplementary Material}

Refer to Web version on PubMed Central for supplementary material. 


\section{Acknowledgements}

We thank Fanny Brun for providing the data underlying Figure 2 and Supplementary Figure S1, and Jesse Norris for providing the data for Supplementary Figure S3.

\section{Bibliography}

1. Hewitt K. Rock avalanches that travel onto glaciers and related developments, Karakoram Himalaya, Inner Asia. Geomorphology. 2009; 103:66-79. DOI: 10.1016/j.geomorph.2007.10.017

2. RGI Consortium. Randolph Glacier Inventory - A dataset of global glacier outlines: Version 6.0. Global Land Ice Measurements from Space (GLIMS); Colorado, USA: 2017. Digital media

3. Farinotti D, et al. A consensus estimate for the ice thickness distribution of all glaciers on Earth. Nature Geoscience. 2019; 12:168-173. DOI: 10.1038/s41561-019-0300-3

4. Armstrong RL, et al. Runoff from glacier ice and seasonal snow in High Asia: separating melt water sources in river flow. Regional Environmental Change. 2019; 19:1249-1261. DOI: 10.1007/ s10113-018-1429-0

5. Akhtar M, Ahmad N, Booij MJ. The impact of climate change on the water resources of HindukushKarakorum-Himalaya region under different glacier coverage scenarios. Journal of Hydrology. 2008; 355:148-163. DOI: 10.1016/j.jhydrol.2008.03.015

6. Immerzeel W, van Beek L, Bierkens M. Climate change will affect the Asian water towers. Science. 2010; 328:1382-1385. DOI: 10.1126/science.1183188 [PubMed: 20538947]

7. Huss M, Hock R. Global-scale hydrological response to future glacier mass loss. Nature Climate Change. 2018; 8:135-140. DOI: 10.1038/s41558-017-0049-x

8. Pritchard HD. Asia's shrinking glaciers protect large populations from drought stress. Nature. 2019; 569:649-654. DOI: 10.1038/s41586-019-1240-1 [PubMed: 31142854]

9. Schlagintweit, H, Schlagintweit, A, Schlagintweit, R. Results of a scientific mission to India and High Asia undertaken between the years 1854 and 1858. Vol. 4. Trubner; London, UK: 1861.

10. Godwin-Austen HH. The glaciers of the Muztagh Range. Proceedings of the Royal Geographic Society. 1864; 34:19-56.

11. Shaw, R. Visits to High Tartary, Yârkand, and Kâshghar: Formerly Chineese Tartary. John Murray; London, UK: 1871.

12. Hayden HH. Notes on certain glaciers in Northwest Kashmir. Records of the Geological Survey of India. 1907; 35:127-137.

13. Zemp M, et al. Global glacier mass balances and their contributions to sea-level rise from 1961 to 2016. Nature. 2019; 568:382-386. DOI: 10.1038/s41586-019-1071-0 [PubMed: 30962533]

14. Berthier E, Brun F. Karakoram glacier mass balances between 2008 and 2016: persistence of the anomaly and influence of a large rock avalanche on Siachen Glacier. Journal of Glaciology. 2019; 65:494-507. DOI: 10.1017/jog.2019.32

15. Dehecq A, et al. Twenty-first century glacier slowdown driven by mass loss in High Mountain Asia. Nature Geoscience. 2019; 12:22-27. DOI: 10.1038/s41561-018-0271-9

16. Quincey DJ, Glasser NF, Cook SJ, Luckman A. Heterogeneity in Karakoram glacier surges. Journal of Geophysical Research: Earth Surface. 2015; 120:1288-1300. DOI: 10.1002/2015JF003515

17. Meier MF, Post A. What are glacier surges? Canadian Journal of Earth Sciences. 1969; 6:807-817. DOI: $10.1139 / \mathrm{e} 69-081$

18. Sevestre H, Benn D. Climatic and geometric controls on the global distribution of surge-type glaciers: implications for a unifying model of surging. Journal of Glaciology. 2015; 61:646-662. DOI: $10.3189 / 2015 J o G 14 J 136$

19. Mason, K. The glaciers of the Karakoram and neighbourhood. Geological Survey of India; 1930.

20. Copland L, et al. Expanded and recently increased glacier surging in the Karakoram. Arctic, Antarctic, and Alpine Research. 2011; 43:503-516. DOI: 10.1657/1938-4246-43.4.503 
21. Hewitt K. The Karakoram Anomaly? Glacier Expansion and the 'Elevation Effect', Karakoram Himalaya. Mountain Research and Development. 2005; 25:332-340. DOI: 10.1659/0276-4741(2005)025[0332:TKAGEA]2.0.CO;2

22. Gardelle J, Berthier E, Arnaud Y. Slight mass gain of Karakoram glaciers in the early twenty-first century. Nature Geoscience. 2012; 5:322-325. DOI: 10.1038/ngeo1450

23. Kääb A, Berthier E, Nuth C, Gardelle J, Arnaud Y. Contrasting patterns of early twenty-firstcentury glacier mass change in the Himalayas. Nature. 2012; 488:495-498. DOI: 10.1038/ nature11324 [PubMed: 22914167]

24. Gardelle J, Berthier E, Arnaud Y, Kääb A. Region-wide glacier mass balances over the PamirKarakoram-Himalaya during 1999-2011. The Cryosphere. 2013; 7:1263-1286. DOI: 10.5194/ tc-7-1263-2013

25. Gardner AS, et al. A reconciled estimate of glacier contributions to sea level rise: 2003 to 2009. Science. 2013; 340:852-857. DOI: 10.1126/science.1234532 [PubMed: 23687045]

26. Kääb A, Treichler D, Nuth C, Berthier E. Brief Communication: Contending estimates of 20032008 glacier mass balance over the Pamir-Karakoram-Himalaya. The Cryosphere. 2015; 9:557564. DOI: $10.5194 /$ tc-9-557-2015

27. Azam MF, et al. Review of the status and mass changes of Himalayan-Karakoram glaciers. Journal of Glaciology. 2018; 64:61-74. DOI: 10.1017/jog.2017.86

28. Brun F, Berthier E, Wagnon P, Kääb A, Treichler D. A spatially resolved estimate of High Mountain Asia glacier mass balances from 2000 to 2016. Nature Geoscience. 2017; 10:668-673. DOI: 10.1038/ngeo2999L3

29. Brun F, et al. Heterogeneous Influence of Glacier Morphology on the Mass Balance Variability in High Mountain Asia. Journal of Geophysical Research: Earth Surface. 2019; 124doi: 10.1029/2018JF004838

30. Scherler D, Strecker MR. Large surface velocity fluctuations of Biafo Glacier, central Karakoram, at high spatial and temporal resolution from optical satellite images. Journal of Glaciology. 2012; 58:569-580. DOI: 10.3189/2012JoG11J096

31. Lv M, et al. Characterizing the behaviour of surge- and non-surge-type glaciers in the Kingata Mountains, eastern Pamir, from 1999 to 2016. The Cryosphere. 2019; 13:219-236. DOI: 10.5194/ tc-13-219-2019

32. Heid T, Kääb A. Repeat optical satellite images reveal widespread and long term decrease in landterminating glacier speeds. The Cryosphere. 2012; 6:467-478. DOI: 10.5194/tc-6-467-2012

33. Scherler D, Bookhagen B, Strecker MR. Spatially variable response of Himalayan glaciers to climate change affected by debris cover. Nature Geoscience. 2011; 4:156-159. DOI: 10.1038/ ngeo1068

34. Rankl M, Kienholz C, Braun M. Glacier changes in the Karakoram region mapped by multimission satellite imagery. The Cryosphere. 2014; 8:977-989. DOI: 10.5194/tc-8-977-2014

35. Minora U, et al. Glacier area stability in the Central Karakoram National Park (Pakistan) in 2001-2010: The "Karakoram Anomaly" in the spotlight. Progress in Physical Geography: Earth and Environment. 2016; 40:629-660. DOI: 10.1177/0309133316643926

36. Bolch T, et al. The state and fate of Himalayan Glaciers. Science. 2012; 336:310-314. DOI: 10.1126/science.1215828 [PubMed: 22517852]

37. Cogley JG. Glacier shrinkage across High Mountain Asia. Annals of Glaciology. 2016; 57:41-49. DOI: 10.3189/2016AoG71A040

38. Herreid S, et al. Satellite observations show no net change in the percentage of supraglacial debriscovered area in northern Pakistan from 1977 to 2014. Journal of Glaciology. 2015; 61:524-536. DOI: $10.3189 / 2015 J o G 14 J 227$

39. Goerlich, F; Paul, F. Surging glaciers everywhere? An updated inventory of surging glaciers for the Pamir Mountains derived from the analysis of multi-temporaloptical satellite data. EGU General Assembly Conference Abstracts, vol. 21 of EGU General Assembly Conference Abstracts; 2019. 5747-2.

40. Chudley TR, Willis IC. Glacier surges in the north-west West Kunlun Shan inferred from 1972 to 2017 Landsat imagery. Journal of Glaciology. 2019; 65:1-12. DOI: 10.1017/jog.2018.94 
41. Bhambri R, Hewitt K, Kawishwar P, Pratap B. Surge-type and surge-modified glaciers in the Karakoram. Scientific Reports. 2017; 7doi: 10.1038/s41598-017-15473-8

42. Mayewski PA, Jeschke PA. Himalayan and Trans-Himalayan glacier fluctuations since AD 1812. Arctic and Alpine Research. 1979; 11:267-287. DOI: 10.1080/00040851.1979.12004137

43. Hewitt K. Glacier change, concentration, and elevation effects in the Karakoram Himalaya, upper Indus basin. Mountain Research and Development. 2011; 31:188-200. DOI: 10.1659/MRDJOURNAL-D-11-00020.1

44. Bhutiyani MR. Mass-balance studies on Siachen glacier in the Nubra valley, Karakoram Himalaya, India. Journal of Glaciology. 1999; 45:112-118. DOI: 10.1017/S0022143000003099

45. Zaman Q, Liu J. Mass balance of Siachen Glacier, Nubra valley, Karakoram Himalaya: facts or flaws? Journal of Glaciology. 2015; 61:1012-1014. DOI: 10.3189/2015JoG15J120

46. Zhou Y, Li Z, Li J, Zhao R, Ding X. Slight glacier mass loss in the Karakoram region during the 1970s to 2000 revealed by KH-9 images and SRTM DEM. Journal of Glaciology. 2017; 63:331342. DOI: $10.1017 /$ jog.2016.142

47. Bolch T, Pieczonka T, Mukherjee K, Shea J. Brief communication: Glaciers in the Hunza catchment (Karakoram) have been nearly in balance since the 1970s. The Cryosphere. 2017; 11:531-539. DOI: 10.5194/tc-11-531-2017

48. Zhou Y, Li Z, Li J, Zhao R, Ding X. Glacier mass balance in the Qinghai-Tibet Plateau and its surroundings from the mid-1970s to 2000 based on Hexagon KH-9 and SRTM DEMs. Remote Sensing of Environment. 2018; 210:96-112. DOI: 10.1016/j.rse.2018.03.020

49. Wang Y, et al. Glacier anomaly over the western Kunlun Mountains, Northwestern Tibetan Plateau, since the 1970s. Journal of Glaciology. 2018; 64:624-636. DOI: 10.1017/jog.2018.53

50. Holzer N, et al. Four decades of glacier variations at Muztagh Ata (eastern Pamir): a multi-sensor study including Hexagon KH-9 and Pleiades data. The Cryosphere. 2015; 9:2071-2088. DOI: 10.5194/tc-9-2071-2015

51. Zhou Y, Li Z, Li J, Zhao R, Ding X. Geodetic glacier mass balance (1975-1999) in the central Pamir using the SRTM DEM and KH-9 imagery. Journal of Glaciology. 2019; 65:309-320. DOI: 10.1017/jog.2019.8

52. von Wissmann, H, Flohn, H. Die heutige Vergletscherung und Schneegrenze in Hochasien mit Hinweisen auf die Vergletscherung der letzten Eiszeit [Today's glacierization and snow line in High Asia, with hints on the glaciation duringt the last ice age (in German)]Abhandlungen der Mathematisch-Naturwissenschaftlichen Klasse. Akademie der Wissenschaften und der Literatur (Verlag der Akademie der Wissenschaften und der Literatur; in Kommission bei F. Steiner); Wiesbaden: 1960.

53. Kick, W. The decline of the last Little Ice Age in High Asia compared with that in the AlpsGlacier fluctuations and climate change. Oerlemans, J, editor. Kluwer; Dordrecht, The Netherlands: 1989. 129-142.

54. Archer DR, Fowler HJ. Spatial and temporal variations in precipitation in the Upper Indus Basin, global teleconnections and hydrological implications. Hydrology and Earth System Sciences. 2004; 8:47-61. DOI: 10.5194/hess-8-47-2004

55. Fowler HJ, Archer DR. Conflicting signals of climatic change in the upper Indus basin. Journal of Climate. 2006; 19:4276-4293. DOI: 10.1175/JCLI3860.1

56. Yadav RR, Park W-K, Singh J, Dubey B. Do the western Himalayas defy global warming? Geophysical Research Letters. 2004; 31:L17201.doi: 10.1029/2004GL020201

57. Treydte KS, et al. The twentieth century was the wettest period in northern Pakistan over the past millennium. Nature. 2006; 440:1179-1182. DOI: 10.1038/nature04743 [PubMed: 16641993]

58. Quincey DJ, et al. Ice velocity and climate variations for Baltoro Glacier, Pakistan. Journal of Glaciology. 2009; 55:1061-1071. DOI: 10.3189/002214309790794913

59. Quincey DJ, et al. Karakoram glacier surge dynamic. Geophysical Research Letters. 2011; 38doi: 10.1029/2011GL049004

60. Archer CL, Caldeira K. Historical trends in the jet streams. Geophysical Research Letters. 2008; 35doi: 10.1029/2008GL033614

61. Finsterwalder R. Die Gletscher des Nanga Parbat, glaziologische Arbeiten der Deutschen Himalaya-Expedition 1934 und ihre Ergebnisse [The glaciers of Nanga Parbat, glaciological works 
of the German Himalays-Expedition and their results (in German)]. Zeitschrift für Gletscherkunde und Glazialgeologie. 1937; 25:57-107.

62. Batura Glacier Investigation Group. The Batura Glacier in the Karakoram mountains and its variations. Scientia Sinica. 1979; 22:958-974. DOI: 10.1360/ya1979-22-8-958

63. Hewitt K, Wake CP, Young GJ, David C. Hydrological investigations at Biafo Glacier, Karakoram Range, Himalaya; an important source of water for the Indus River. Annals of Glaciology. 1989; 13:103-108. DOI: $10.3189 /$ S0260305500007710

64. Gardner JS, Hewitt K. A surge of Bualtar Glacier, Karakoram Range, Pakistan: A possible landslide trigger. Journal of Glaciology. 1990; 36:159-162. DOI: 10.3189/S0022143000009394

65. Wake CP, Searle MP. Rapid advance of Pumarikish Glacier, Hispar Glacier Basin, Karakoram Himalaya. Journal of Glaciology. 1993; 39:204-206. DOI: 10.3189/S0022143000015847

66. Mayer C, Lambrecht A, Beló M, Smiraglia C, Diolaiuti G. Glaciological characteristics of the ablation zone of Baltoro glacier, Karakoram, Pakistan. Annals of Glaciology. 2006; 43:123-131. DOI: $10.3189 / 172756406781812087$

67. Copland L, et al. Glacier velocities across the central karakoram. Annals of Glaciology. 2009; 50:41-49. DOI: $10.3189 / 172756409789624229$

68. Hewitt K. Tributary glacier surges: an exceptional concentration at Panmah Glacier, Karakoram Himalaya. Journal of Glaciology. 2007; 53:181-188. DOI: 10.3189/172756507782202829

69. Kapnick SB, Delworth TL, Ashfaq M, Malyshev S, Milly PCD. Snowfall less sensitive to warming in Karakoram than in Himalayas due to a unique seasonal cycle. Nature Geoscience. 2014; 7:834840. DOI: $10.1038 /$ ngeo2269

70. Forsythe N, Fowler HJ, Li X-F, Blenkinsop S, Pritchard D. Karakoram temperature and glacial melt driven by regional atmospheric circulation variability. Nature Climate Change. 2017; 7:664670. DOI: $10.1038 /$ nclimate3361

71. Li X-F, Fowler HJ, Forsythe N, Blenkinsop S, Pritchard D. The Karakoram/Western Tibetan vortex: seasonal and year-to-year variability. Climate Dynamics. 2018; 51:3883-3906. DOI: 10.1007/s00382-018-4118-2

72. Maussion F, et al. Precipitation seasonality and variability over the Tibetan Plateau as resolved by the High Asia Reanalysis. Journal of Climate. 2013; 27:1910-1927. DOI: 10.1175/JCLID-13-00282.1

73. Curio J, Maussion F, Scherer D. A 12-year high-resolution climatology of atmospheric water transport over the Tibetan Plateau. Earth System Dynamics. 2015; 6:109-124. DOI: 10.5194/ esd-6-109-2015

74. Cannon F, Carvalho LMV, Jones C, Norris J. Winter westerly disturbance dynamics and precipitation in the western Himalaya and Karakoram: a wave-tracking approach. Theoretical and Applied Climatology. 2016; 125:27-44. DOI: 10.1007/s00704-015-1489-8

75. Cannon F, Carvalho LMV, Jones C, Bookhagen B. Multi-annual variations in winter westerly disturbance activity affecting the Himalaya. Climate Dynamics. 2015; 44:441-455. DOI: 10.1007/ s00382-014-2248-8

76. Norris J, Carvalho LMV, Jones C, Cannon F. Deciphering the contrasting climatic trends between the central Himalaya and Karakoram with 36 years of WRF simulations. Climate Dynamics. 2019; 52:159-180. DOI: 10.1007/s00382-018-4133-3

77. Mölg T, Maussion F, Scherer D. Mid-latitude westerlies as a driver of glacier variability in monsoonal High Asia. Nature Climate Change. 2014; 4:68-73. DOI: 10.1038/nclimate2055

78. Palazzi E, von Hardenberg J, Provenzale A. Precipitation in the Hindu-Kush Karakoram Himalaya: Observations and future scenarios. Journal of Geophysical Research: Atmospheres. 2013; 118:85100. DOI: 10.1029/2012JD018697

79. Hasson S, Böhner J, Lucarini V. Prevailing climatic trends and runoff response from HindukushKarakoram-Himalaya, upper Indus Basin. Earth System Dynamics. 2017; 8:337-355. DOI: 10.5194/esd-8-337-2017

80. Asad F, et al. Are Karakoram temperatures out of phase compared to hemispheric trends? Climate Dynamics. 2017; 48:3381-3390. DOI: 10.1007/s00382-016-3273-6 
81. de Kok RJ, Tuinenburg OA, Bonekamp PNJ, Immerzeel WW. Irrigation as a potential driver for anomalous glacier behavior in High Mountain Asia. Geophysical Research Letters. 2018; 45:2047-2054. DOI: 10.1002/2017GL076158 [PubMed: 29937602]

82. Cook BI, Shukla SP, Puma MJ, Nazarenko LS. Irrigation as an historical climate forcing. Climate Dynamics. 2015; 44:1715-1730. DOI: 10.1007/s00382-014-2204-7

83. Bashir F, Zeng X, Gupta H, Hazenberg P. A hydrometeorological perspective on the Karakoram anomaly using unique valley-based synoptic weather observations. Geophysical Research Letters. 2017; 44:10470-10478. DOI: 10.1002/2017GL075284

84. Lee E, Sacks WJ, Chase TN, Foley JA. Simulated impacts of irrigation on the atmospheric circulation over Asia. Journal of Geophysical Research: Atmospheres. 2011; 116doi: 10.1029/2010JD014740

85. Singh D, et al. Distinct influences of land cover and land management on seasonal climate. Journal of Geophysical Research: Atmospheres. 2018; 123:12017-12039. DOI: 10.1029/2018JD028874

86. Wang R, Liu S, Shangguan D, Radić V, Zhang Y. Spatial heterogeneity in glacier mass-balance sensitivity across High Mountain Asia. Water. 2019; 11:776.doi: 10.3390/w11040776

87. Sakai A, Fujita K. Contrasting glacier responses to recent climate change in high-mountain Asia. Scientific Reports. 2017; 7doi: 10.1038/s41598-017-14256-5

88. Untersteiner N. Glacial-meteorological analyses in the Karakoram (in German with English abstract). Archiv für Meteorologie, Geophysik und Bioklimatologie, Serie B. 1957; 8:1-30. DOI: 10.1007/BF02260293

89. Mihalcea C, et al. Ice ablation and meteorological conditions on the debris-covered area of Baltoro glacier, Karakoram, Pakistan. Annals of Glaciology. 2006; 43:292-300. DOI: 10.3189/172756406781812104

90. Bonekamp PN, de Kok RJ, Collier E, Immerzel WW. Contrasting meteorological drivers of the glacier mass balance between the Karakoram and central Himalaya. Frontiers in Earth Science. 2019; 7:107.doi: 10.3389/feart.2019.00107

91. Hewitt, K. Glaciers of the Karakoram Himalaya. Springer; Dordrecht, Heidelberg, New York, London: 2014.

92. Copernicus Climate Change Service. [last accessed July 2019] ERA5: Fifth generation of ECMWF atmospheric reanalyses of the global climate. 2017. Available at https://cds.climate.copernicus.eu/ cdsapp\#!/home [Online resource]

93. Shea JM, Immerzeel WW, Wagnon P, Vincent C, Bajracharya S. Modelling glacier change in the Everest region, Nepal Himalaya. The Cryosphere. 2015; 9:1105-1128. DOI: 10.5194/ tc-9-1105-2015

94. Benn DI, Fowler AC, Hewitt IHS. A general theory of glacier surges. Journal of Glaciology. 2019; n.a.:1-16. DOI: $10.1017 /$ jog.2019.62

95. Kääb A, et al. Massive collapse of two glaciers in western Tibet in 2016 after surge-like instability. Nature Geoscience. 2018; 11:114-120. DOI: 10.1038/s41561-017-0039-7

96. Gilbert A, et al. Mechanisms leading to the 2016 giant twin glacier collapses, Aru Range, Tibet. The Cryosphere. 2018; 12:2883-2900. DOI: 10.5194/tc-12-2883-2018

97. Dimri AP, Kumar D, Choudhary A, Maharana P. Future changes over the Himalayas: Mean temperature. Global and Planetary Change. 2018; 162:235-251. DOI: 10.1016/j.gloplacha. 2018.01.014

98. Kraaijenbrink P, Lutz A, Bierkens M, Immerzeel W. Impact of a global temperature rise of 1.5 degrees Celsius on Asia's glaciers. Nature. 2017; 549:257-260. DOI: 10.1038/nature23878 [PubMed: 28905897]

99. Quincey D, et al. The changing water cycle: the need for an integrated assessment of the resilience to changes in water supply in High-Mountain Asia. Wiley Interdisciplinary Reviews: Water. 2018; 5:e1258.doi: 10.1002/wat2.1258

100. Benn DI, et al. Response of debris-covered glaciers in the Mount Everest region to recent warming, and implications for outburst flood hazards. Earth-Science Reviews. 2012; 114:156174. DOI: $10.1016 /$ j.earscirev.2012.03.008

101. Anderson LS, Anderson RS. Modeling debris-covered glaciers: response to steady debris deposition. The Cryosphere. 2016; 10:1105-1124. DOI: 10.5194/tc-10-1105-2016 
102. Harrison WD, Post AS. How much do we really know about glacier surging? Annals of Glaciology. 2003; 36:1-6. DOI: 10.3189/172756403781816185

103. Kumar P, et al. Response of Karakoram-Himalayan glaciers to climate variability and climatic change: A regional climate model assessment. Geophysical Research Letters. 2015; 42:18181825. DOI: 10.1002/2015GL063392 


\section{Box 1}

\section{Peculiarities of Karakoram glaciers}

Compared to other regions of High Mountain Asia, glaciers in the Karakoram are unusually large ${ }^{2}$, and have exceptional elevation ranges. The extremely high altitudes, reaching above $8,000 \mathrm{~m}$ a.s.l. at times, cause precipitation to occur as snow during most of the year, giving rise to a year-round accumulation regime ${ }^{43}$. The characteristic, steep mountain walls confining the accumulation area of many glaciers cause orographic concentration of snow (Turkestan- and Mustagh-type glaciers ${ }^{43}$ ) and are source of extensive debris ${ }^{1}$. The latter covers the ablation zones of many glaciers in the region. The debris cover, in turn, makes the glacier response to external forcing non-linear ${ }^{100}$, and results in large glacier portions persisting at lower elevations when compared to debrisfree glaciers responding to the same climate forcing ${ }^{101}$. Widespread surging activity gives rise to some peculiar geomorphic features, such as lobed medial moraines, strandlines, ice foliation, and rugged, strongly-crevassed glacier surfaces ${ }^{20}$. 


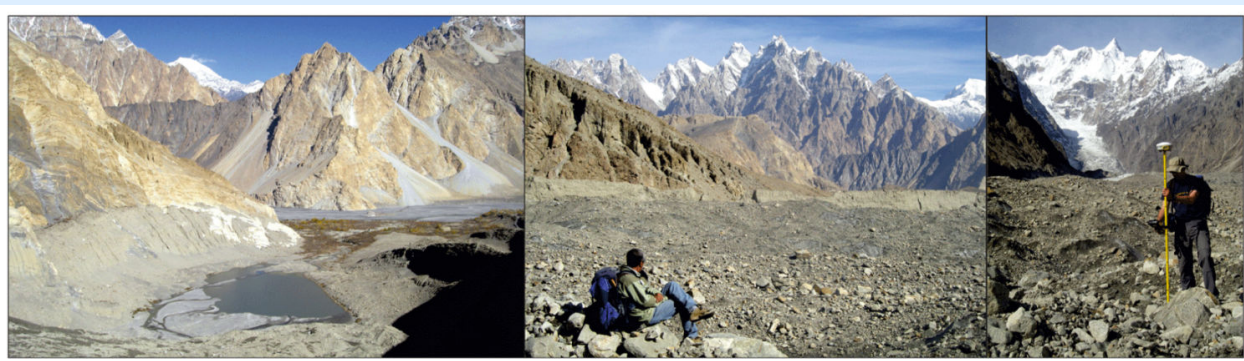




\section{Box 2}

\section{Classical surging mechanisms}

Two main mechanisms have been proposed to explain glacier surging ${ }^{102}$ : thermal and hydrological control. Both attribute the ultimate cause of the acceleration in ice motion to an increase in subglacial water pressure and the resulting enhancement of sliding at the glacier base.

- In thermally controlled surges, changes in basal temperature promote a positive feedback between ice deformation, basal melt, pore water pressure, and sliding. This mechanism is comparatively slow, and leads to seasonally independent surge initiation- and termination-phases that are several years long.

- In hydrologically controlled surges, the increase in sliding velocities are directly caused by a change in the efficiency, and therefore water pressure, of the subglacial drainage system. This mechanism is much faster than the thermal one, and results in phases of winter initiation and summer termination, both of days to weeks duration.

Recent work ${ }^{94}$ proposed a unifying theory that recognises the importance of both heat and water, casting surges as an imbalance in enthalpy. This imbalance occurs only within narrow climatic and geometric envelopes ${ }^{18}$, both of which can be found in the Karakoram and neighbouring regions. 


\section{Box 3}

\section{Karakoram climate}

In contrast to the neighbouring Himalaya, which are under the influence of the Indian monsoon, the Karakoram's climate ${ }^{54}$ is predominantly influenced by westerly weather systems and the Tibetan anticyclone. Most of the annual precipitation falls in spring and winter, during which the westerly influence dominates (Fig. 1b). The Mediterranean and the Caspian Sea are the main moisture sources during such conditions. The monsoon makes sporadic incursions during summer, with amounts of precipitation rapidly decreasing from south-east to north-west. Moisture from the Arabian Sea is brought to the region when low-pressure systems develop over Pakistan. In such cases, precipitation decreases sharply northward due to orographic shielding. 

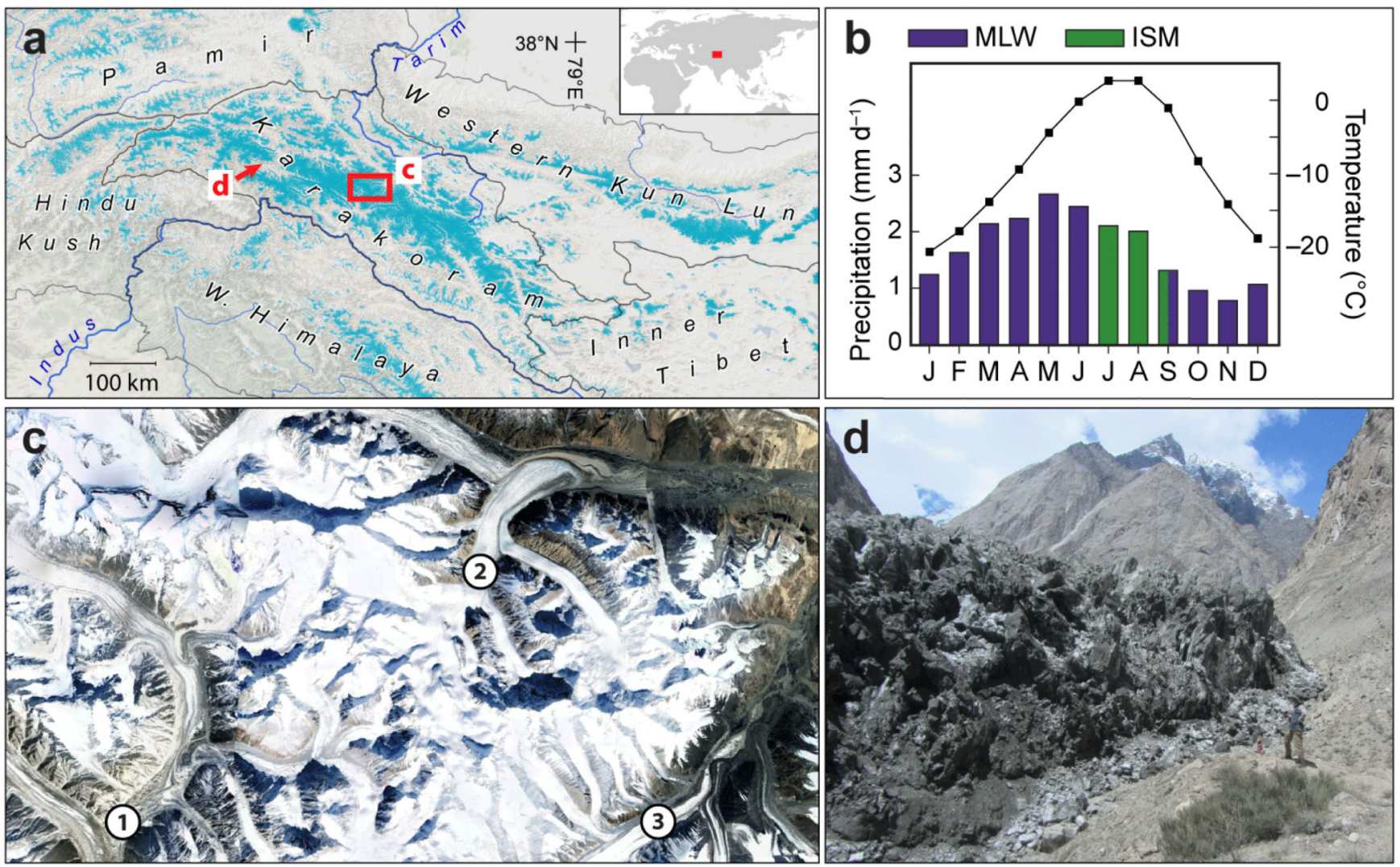

Figure 1. Distribution of Karakoram glaciers and climate characteristic.

a Glacier coverage and regions as per Randolph Glacier Inventory ${ }^{2}$ version 6. b Regional average temperature (connected squares) and precipitation (bars) for the period 1989-2007, re-drawn from ref. ${ }^{103}$. The influence of Mid-Latitude Westerlies (MLW) and the Indian Summer Monsoon (ISM) is shown based on the classification by ref. ${ }^{90}$. c GoogleEarth image with looped and folded moraines providing indications of past surges at (1) Panmah, (2) South Skamri, and (3) Sarpo Langgo Glacier. d Terminus of Shishper Glacier in May 2019, showing clear sign of recent advance (image credit: Rina Seed). Note the person for scale. 


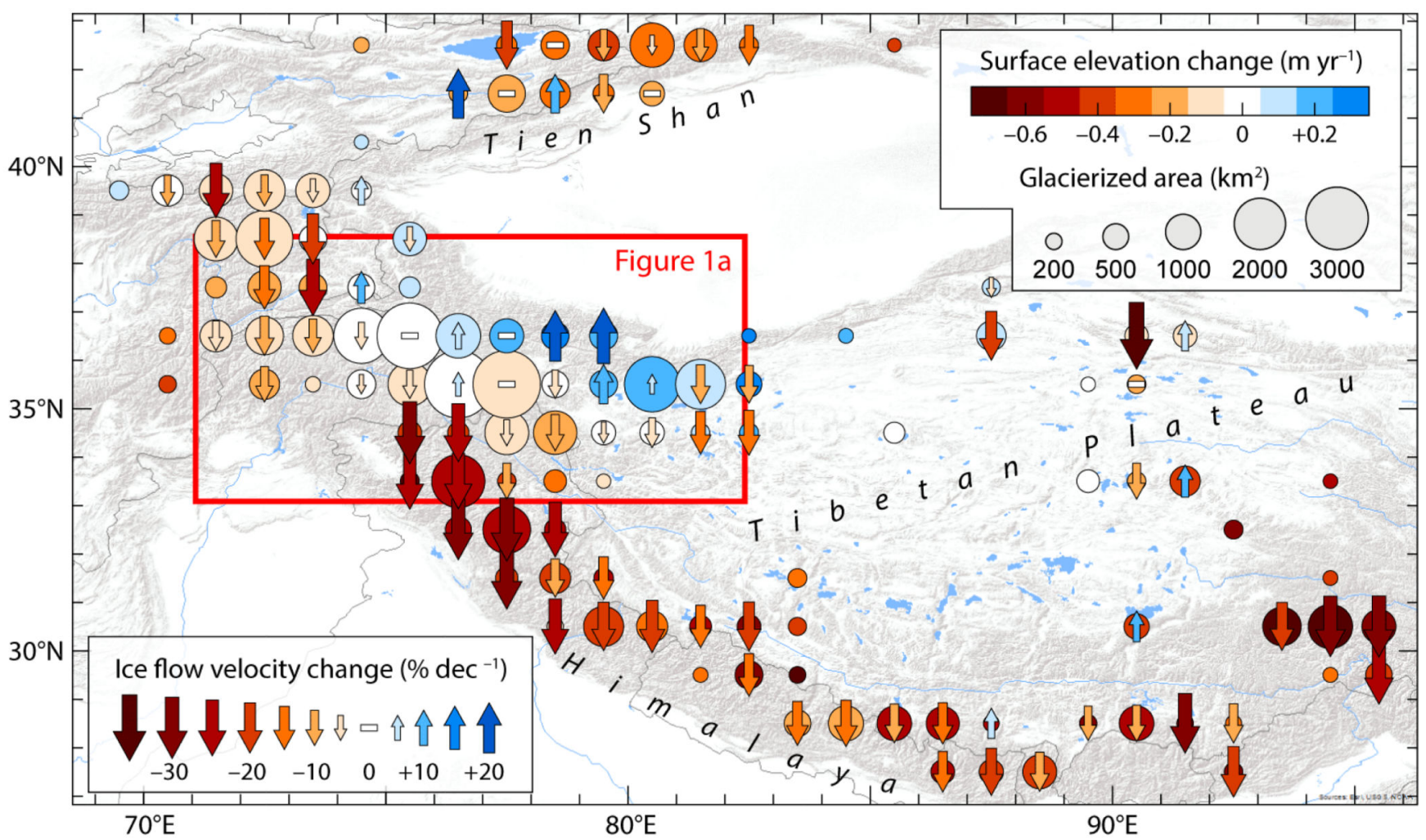

Figure 2. Recent glacier changes in High Mountain Asia.

The rate of glacier surface elevation change ${ }^{28}$ is shown together with changes in ice flow velocity ${ }^{15}$ for the period 2000-2016. The size of the circles is proportional to the glacier area. Data are aggregated on a $1^{\circ} \times 1^{\circ}$ grid, and uncertainties are shown in Supplementary Figure S1. The red box indicates the area shown in Figure 1a and includes the Karakoram. 

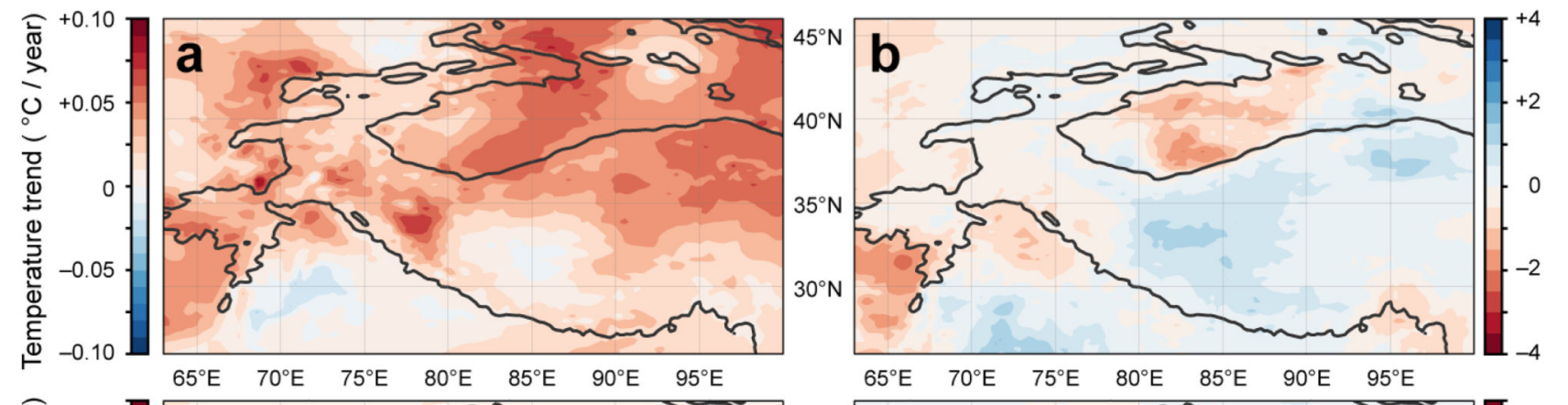

Figure 3. Potential meteo-climatic drivers of the Karakoram Anomaly.

The spatial distribution of linear trends in (a) summer (JJA) temperature, (b) annual precipitation, (c) summer net shortwave (SW) radiation, and (d) summer net longwave (LW) radiation is shown for the time period 1980-2018. The representations are based on ERA5 data $^{92}$. Trend significances and a comparison to the high-resolution climate model results by ref. ${ }^{76}$ are provided in Supplementary Figures S3 and S2, respectively. A 2,000 m contour line (black) is provided for orientation. 
1. External processes

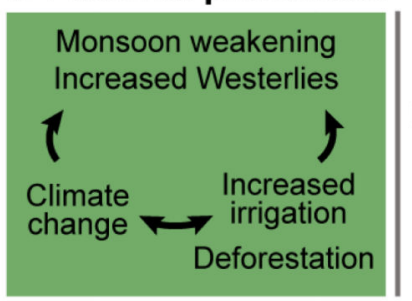

Relative level of confidence / understanding

certain

intermediate

uncertain

\section{Climate forcing}

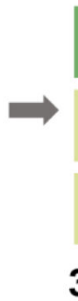

\section{Glacier properties}

\section{Extent}

and shape

Ice
thickness

Topography

Debris-cover

thickness

Subglacial properties

\section{Glacier response}

\section{Near-stable extents \\ 5. Downstream impacts}

Zero to positive

mass changes

Increased to stable

ice flow speeds

Glacier surging
Reduced streamflow

Glacier hazards

Figure 4. Schematic of the process-chain leading to anomalous glacier evolution.

For every element, a relative level of confidence in its characterization or understanding is given. The confidence level is based upon the authors' expert judgement and literature review. 